\title{
Punicalagin and Ellagic Acid Demonstrate Antimutagenic Activity and Inhibition of Benzo[a]pyrene Induced DNA Adducts
}

\author{
Maryam Zahin, ${ }^{1,2}$ Iqbal Ahmad, ${ }^{1}$ Ramesh C. Gupta, ${ }^{2,3}$ and Farrukh Aqil ${ }^{2,4}$ \\ ${ }^{1}$ Department of Agricultural Microbiology, Aligarh Muslim University, Aligarh 202002, India \\ ${ }^{2}$ James Graham Brown Cancer Center, University of Louisville, Louisville, KY 40202, USA \\ ${ }^{3}$ Department of Pharmacology and Toxicology, University of Louisville, Louisville, KY 40202, USA \\ ${ }^{4}$ Department of Medicine, University of Louisville, Delia Baxter II, Room 304B, 580 S. Preston Street, Louisville, KY 40202, USA
}

Correspondence should be addressed to Farrukh Aqil; f0aqil01@louisville.edu

Received 1 March 2014; Accepted 22 April 2014; Published 14 May 2014

Academic Editor: Davor Zeljezic

Copyright (C) 2014 Maryam Zahin et al. This is an open access article distributed under the Creative Commons Attribution License, which permits unrestricted use, distribution, and reproduction in any medium, provided the original work is properly cited.

\begin{abstract}
Punicalagin (PC) is an ellagitannin found in the fruit peel of Punica granatum. We have demonstrated antioxidant and antigenotoxic properties of Punica granatum and showed that PC and ellagic acid (EA) are its major constituents. In this study, we demonstrate the antimutagenic potential, inhibition of BP-induced DNA damage, and antiproliferative activity of PC and EA. Incubation of BP with rat liver microsomes, appropriate cofactors, and DNA in the presence of vehicle or PC and EA showed significant inhibition of the resultant DNA adducts, with essentially complete inhibition (97\%) at $40 \mu \mathrm{M}$ by PC and $77 \%$ inhibition by EA. Antimutagenicity was tested by Ames test. PC and EA dose-dependently and markedly antagonized the effect of tested mutagens, sodium azide, methyl methanesulfonate, benzo[a]pyrene, and 2-aminoflourine, with maximum inhibition of mutagenicity up to 90 percent. Almost all the doses tested (50-500 $\mu \mathrm{M})$ exhibited significant antimutagenicity. A profound antiproliferative effect on human lung cancer cells was also shown with PC and EA. Together, our data show that PC and EA are pomegranate bioactives responsible for inhibition of BP-induced DNA adducts and strong antimutagenic, antiproliferative activities. However, these compounds are to be evaluated in suitable animal model to assess their therapeutic efficacy against cancer.
\end{abstract}

\section{Introduction}

Over the past few decades, tremendous outcomes have been resulted by exploring antioxidant and antimutagenic potential of medicinal plants. It is widely accepted that oxidative modification of DNA, protein, lipids, and small cellular molecules by both exogenous and endogenous reactive oxygen species including free radicals and nonfree radicals plays an important role in a wide range of common diseases including cancer and age related degenerative diseases $[1,2]$. The human body possesses innate defence mechanisms to counter free radicals. Plant secondary metabolites such as phenolics, flavonoids, and terpenoids play an important role in the defence against free radicals [3]. Moreover, these natural antioxidants may reduce or inhibit the mutagenic potential of mutagens, promutagens, and carcinogens $[4,5]$. Therefore, the discovery and the exploration of compounds possessing antioxidant, antimutagenic, and anticancer properties are now fetching great practical and therapeutic significance.

The formation of DNA adducts (i.e., carcinogens covalently bound to DNA) is widely considered a prerequisite for the initiation and progression of cancer development. Many carcinogens are known to induce the formation of DNA adducts [6] and the presence of DNA adducts in humans has been strongly correlated with an increased risk of cancer development [7]. For example, human studies have shown a higher accumulation of tissue DNA adducts in cigarette smokers than in nonsmokers or individuals who have never smoked, indicating that DNA adduct formation is a viable target for the treatment of cancer [8].

Benzo[a]pyrene (BP) is one of the most potent and extensively studied carcinogens. In a cellular system, BP is metabolized to the electrophilic metabolite, benzo[a]pyrene-7,8diol-9,10-epoxide (BPDE), that attaches covalently to DNA 


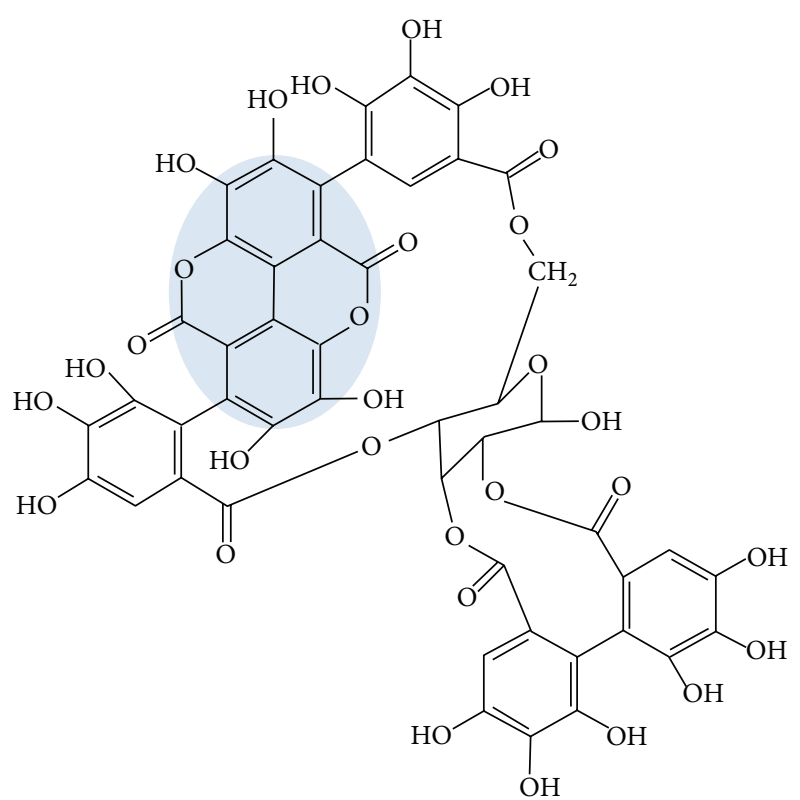

Punicalagin

(a)<smiles></smiles>

Ellagic acid

(b)

FIGURE 1: Chemical structures of punicalagin and ellagic acid.

bases, primarily deoxyguanosine. Inflammatory response to chemical carcinogens and formation of DNA adducts are generally considered a prerequisite in the process of chemical carcinogenesis [9]. Accumulation of DNA adducts resulting from chronic exposure to low-level environmental carcinogens has been used as a possible measure of exposure to carcinogens and cancer risk assessment [10].

Natural antimutagens from edible and medicinal plants are of particular importance because they may be useful for inhibition of DNA adducts leading to human cancer prevention and have no undesirable xenobiotic effects on living organisms [11, 12]. Encouraging reports on antimutagenic properties of edible plants have led to increase interest in search of natural phytoantimutagens from medicinal plants $[13,14]$. Among them is Punica granatum (pomegranate), which have been used widely as antimicrobial, antioxidant, antimutagenic, and anticancer [15-17]. Pomegranate has been shown to possess high amount of ellagitannins (ETs) such as punicalagin (PC), punicalin, gallagic acid, ellagic acid (EA), and EA-glycosides [18, 19].

Punicalagin and ellagic acid (Figure 1) emerged out to be the most elaborated groups of compounds, known for their potential role in various biological activities. Like other polyphenols, PC, EA, and their derived metabolites possess a wide range of biological activities, which suggested that they could have beneficial effects on human health. PC and EA have antioxidant functions and possess strong anti-inflammatory, antiproliferative, hepatoprotective, and antigenotoxic properties [20-23].

PC and EA also exhibit anticancer properties in vitro and in vivo $[17,24]$. However, studies on antimutagenic potential on these compounds are scanty. Therefore, considering our results and previous findings by other workers, we extended our study to isolate the key compounds, PC from P. granatum peel extracts. In this study we demonstrate antimutagenic properties of PC and EA against the mutagenicity induced by mutagens (sodium azide and methyl methanesulfonate) and promutagens (BP and 2AF) in Ames Salmonella assay. This study, to the best of our knowledge, is the first to show antimutagenic properties against a panel of mutagens/carcinogens and procarcinogens. We also examined protective effect of PC and EA against BP-induced DNA adducts and antiproliferative activity against lung cancer cells in vitro.

\section{Materials and Methods}

2.1. Bacterial Strains and Chemicals. The Salmonella typhimurium strains TA97a, TA98, TA100, and TA102 were kindly provided by Prof. B. N. Ames, University of California, Berkeley, USA. The details of the strains are provided in the Supplementary Table S1 (see Supplementary Material available online at http://dx.doi.org/10.1155/2014/467465). Sodium azide $\left(\mathrm{NaN}_{3}\right)$ was purchased from HiMedia Lab. (Mumbai, India). D-glucose-6-phosphate disodium salt, nicotinamide adenine dinucleotide phosphate sodium salt, sodium phosphate, ammonium molybdate, neocuproine, L-histidine monohydrate, D-biotin, 2-aminofluorene (2AF), benzo[a]pyrene, and ellagic acid were purchased from SigmaAldrich (St. Louis, MO, USA). Methyl methanesulfonate (MMS) and trichloroacetic acid were purchased from Sisco Research Laboratories Pvt. Ltd., Mumbai, India. All other reagents used to prepare buffers and media were of analytical grade. 
2.2. Preparation of the Extract and Isolation of Punicalagin. Punica granatum (pomegranate) fruits peel extracts $(30 \%$ enriched for punicalagins) were purchased from Pharmanza Inc. (Gujarat, India). The extracts were prepared by dissolving $10 \mathrm{~g}$ of peel powder in $5 \mathrm{vol}(50 \mathrm{~mL})$ of water. Samples were then centrifuged at $6000 \mathrm{~g}$ for $10 \mathrm{~min}$ and decanted and pooled extracts from three extractions were dried under reduced pressure using Rota-vapor at $45^{\circ} \mathrm{C}$. PC was isolated by Amberlite XAD-16 and C18 column chromatography as described [19]. Isolated PC was at least $97 \%$ pure and essentially free of EA as determined by HPLC-UV.

2.3. Antimutagenicity Assay. The Salmonella histidine point mutation assay described by Maron and Ames [25] was used to test the antimutagenic activity of PC and EA as described earlier $[13,26]$. In the preincubation experiment, test compounds and mutagen, each having a volume of $0.1 \mathrm{~mL}$ of varying concentrations, were preincubated at $37^{\circ} \mathrm{C}$ for $30 \mathrm{~min}$ and then $0.1 \mathrm{~mL}$ of $1 \times 10^{7} \mathrm{CFU} / \mathrm{mL}$ density of the bacterial culture was added, followed by the addition of $2.5 \mathrm{~mL}$ of top agar at $45^{\circ} \mathrm{C}$ (containing $0.5 \% \mathrm{NaCl}$ and $0.6 \%$ agar) supplemented with $0.5 \mathrm{mM}$ histidine-biotin. The influence of metabolic activation of promutagens, $\mathrm{BP}$ and $2 \mathrm{AF}$ was tested using $500 \mu \mathrm{L}$ of $\mathrm{S} 9$ mixture $(0.04 \mathrm{mg}$ proteins $/ \mathrm{mL}$ of $\mathrm{mix})$. The $\mathrm{S} 9$ microsome fraction was prepared from the livers of rats treated with Aroclor 1254 using standard protocols [27]. The combined solutions were vortexed and poured onto minimal glucose plates ( $40 \%$ glucose solution and Vogel Bonner medium). The plates were incubated at $37^{\circ} \mathrm{C}$ for $48 \mathrm{~h}$ and the numbers of histidine-independent revertants colonies were scored.

Survival of the bacteria was routinely monitored for each experiment. Parallel controls were run with compounds alone at all concentrations to test the possible toxicity. The concentrations of the test samples for investigating the antimutagenicity were $50,100,200$, and $500 \mu \mathrm{M}$. PC and EA were tested against mutagens sodium azide $(1.5 \mu \mathrm{g} / 0.1 \mathrm{~mL} /$ plate $)$ and MMS $(1 \mu \mathrm{g} / 0.1 \mathrm{~mL} /$ plate $)$ as well as against promutagens, $\mathrm{BP}$ and 2AF in TA97a and TA98 (frame shift mutation), TA100 (base pair substitution), and TA102 (transition mutation) tester strains (Supplementary Table S1). All the test samples and mutagens were dissolved in DMSO (final conc., $0.01 \%)$. In each case, there was no toxicity observed and the numbers of spontaneous revertants were identical with the DMSO vehicle control. Non-toxic concentrations were categorized as those where there was a well-developed lawn, almost similar size of colonies, and no statistical difference in the number of spontaneous revertants in test and control plates. Plates were set up in triplicate for each concentration and the entire experiment was repeated three times. Inhibition of mutagenicity was expressed as percentage decrease of reverse mutation and calculated as

$$
\text { Percent inhibition }=\left[\frac{(a-b)}{(a-c)}\right] \times 100,
$$

where $a=$ number of histidine revertants induced by mutagen, $b=$ number of histidine revertants induced by mutagen in the presence of test compound, and $c=$ number of revertants induced in negative control.
2.4. Microsomal BP-DNA Adducts. st-DNA $(300 \mu \mathrm{g} / \mathrm{mL})$ was preincubated with $50 \mathrm{mM}$ Tris- $\mathrm{HCl}(\mathrm{pH} 7.5), 1 \mathrm{mM}$ $\mathrm{MgCl}_{2}, 2.5 \mathrm{mM}$ glucose-6-phosphate, $1 \mathrm{U} / \mathrm{mL}$ G6PDH, $0.5 \mathrm{mM} \mathrm{NADP}+$, and $\alpha$-naphthoflavone-induced rat liver microsomal proteins $(1 \mathrm{mg} / \mathrm{mL})$ in $1 \mathrm{~mL}$ for $10 \mathrm{~min}$, in the presence of vehicle alone and PC and EA at 20 and $40 \mu \mathrm{M}$. $\mathrm{BP}$ dissolved in DMSO was added at a final concentration of $1 \mu \mathrm{M}$. The incubation was continued for another $30 \mathrm{~min}$ at $37^{\circ} \mathrm{C}$ and then reaction was terminated by the addition of EDTA and centrifugation $(9,000 \mathrm{~g} ; 10 \mathrm{~min})$. DNA was isolated from the supernatant by removal of RNA and proteins by digestions with RNases $\mathrm{A}$ and $\mathrm{T} 1$ and proteinase $\mathrm{K}$ and a series of extractions with phenol, phenol: Sevag (chloroform: isoamyl alcohol, 24:1), and Sevag, followed by precipitation of the DNA with ethanol [29]. The DNA concentration was estimated spectrophotometrically.

2.5. Analysis of DNA Adducts. DNA adducts were analyzed by ${ }^{32}$ P-postlabeling as described earlier [29]. Briefly, $10 \mu \mathrm{g}$ of DNA was digested with micrococcal nuclease and spleen phosphodiesterase (MN/SPD). Before further treatment with nuclease P1 to enrich DNA adducts, an aliquot was removed for evaluation of normal nucleotide levels. DNA adducts and normal nucleotides were labelled with $\left[\gamma^{-32} \mathrm{P}\right]$ ATP and T4 polynucleotide kinase. Labelled adducts were separated by multidirectional polyethyleneimine (PEI)-cellulose TLC using the following solvents: D1, $1.0 \mathrm{M}$ sodium phosphate, $\mathrm{pH}$ 6.0; D3, $4 \mathrm{M}$ lithium formate/7 $\mathrm{M}$ urea, $\mathrm{pH}$ 3.5; D4, $4 \mathrm{M}$ ammonium hydroxide/isopropanol (1:0.9); and D5, $1.7 \mathrm{M}$ sodium phosphate, $\mathrm{pH}$ 6.0. Normal nucleotides were resolved in $180 \mathrm{mM}$ sodium phosphate, $\mathrm{pH} 6.0$, by one-directional PEI-cellulose TLC. DNA adducts and normal nucleotides were detected and quantified by Packard InstantImager.

2.6. Cell Proliferation Assay and Measurements of Cell Viability. Inhibition of cell proliferation by PC and EA was measured with the MTT assay. Human lung cancer A549 and H1299 cells were obtained from ATCC (Manassas, VA, USA) and maintained in DMEM supplemented with $10 \%$ fetal calf serum (FCS), $1 \%$ penicillin/streptomycin. Cells were plated in 96 -well culture plates $\left(5 \times 10^{3}\right.$ cells/well). After $24 \mathrm{~h}$ incubation, cells were treated with vehicle alone $(0.1 \%$ DMSO) and PC and EA (12.5-200 $\mu \mathrm{g} / \mathrm{mL})$ extracts for $48 \mathrm{~h}$. Then, the culture medium was replaced by $100 \mu \mathrm{L}$ of fresh medium containing $0.5 \mathrm{mg} / \mathrm{mL} \mathrm{MTT}$, and the plates were incubated for $2 \mathrm{~h}$ at $37^{\circ} \mathrm{C}$. The medium was then removed and was replaced by $200 \mu \mathrm{L}$ of DMSO to solubilize the converted purple dye. The absorbance was measured with a spectrophotometer microplate reader at a wavelength of $570 \mathrm{~nm}$.

2.7. Statistical Analysis. The results are presented as the average and standard error of three experiments with triplicate plates/dose/experiment. The regression analysis was carried out in Microsoft Excel 2007 between percent inhibition of mutagenicity and log values of concentrations of the plant extract. 


\section{Results}

Natural products have attracted much attention with respect to their benefits to human health and protective effects in various diseases including cancer [30]. We have previously demonstrated the antimicrobial [16], antioxidant, and antimutagenic potential and phytochemical analysis of Punica granatum $[15,19]$. In this study we demonstrate the inhibition of BP-induced DNA adducts and antimutagenic and antiproliferative activities of PC and EA, the key components of pomegranate.

3.1. Evaluation of Mutagenicity of Tested Compounds. The mutagenicity and antimutagenicity of a compound can be detected using Ames test using specific indicator strains of Salmonella typhimurium [25]. No toxicity of PC and EA was found at tested $50-500 \mu \mathrm{M}$ concentrations as depicted in Tables 1-8 when tested in the absence of S9 fraction in Ames Salmonella typhimurium strains. However, at few concentrations there was slight but insignificant increase in the $\mathrm{His}^{+}$revertants compared to spontaneous. No mutagenic activity of either of the compounds, PC or EA, was detected when investigated on any of Salmonella tester strains, TA97a, TA98, TA100, and TA102 either with or without S9 activation by plate incorporation assay (Tables $1-8$ ).

3.2. PC and EA Are Highly Antimutagenic. The antimutagenic potential of PC and EA was evaluated using Ames Salmonella tester strains against direct acting mutagens $\left(\mathrm{NaN}_{3}\right.$ and MMS), in the absence of S9, as well as against promutagens (BP and 2AF) with Aroclor induced rat liver S9. In the absence of test compounds these mutagens induced $\mathrm{His}^{+}$revertants.

We have previously demonstrated that the methanol extract of Punica granatum has very high antimutagenic potential and contains $\mathrm{PC}$ and EA in addition to other trace compounds [15]. To evaluate the active principle, we further tested, in this study, PC and EA for antimutagenic potential at $50,100,250$, and $500 \mu \mathrm{M}$ concentrations. The tested concentrations by plate-incorporation assay showed no sign of toxicity and mutagenicity to Salmonella typhimurium strains, either alone or in the presence of S9 mix.

BP- and 2AF-induced high number of $\mathrm{His}^{+}$revertants in tester strains. $\mathrm{PC}$ showed a significant $(P<0.005)$ inhibition of BP- and 2AF-induced mutagenicity tested in the presence of S9 mix. At $500 \mu \mathrm{M}$ concentration, PC inhibited $2 \mathrm{AF}-$ and BP-induced mutagenicity in the range of $76.7 \%$ to $85.0 \%$ (Tables 1 and 2). The effect of PC was dose dependent as determined by regression analysis with the $R^{2}$ values ranging between 0.91 and 0.99 .

Similarly, PC at the highest tested concentration $(500 \mu \mathrm{M})$ showed significant antimutagenicity against $\mathrm{NaN}_{3}$ and MMS. It inhibited sodium azide induced mutagenicity by $74.4 \%$ in TA97a followed by TA100 (74.3\%), TA98 (65.3\%), and TA102 (59.8\%) strains as depicted in Table 3. MMS ( $1 \mu \mathrm{g})$, when incubated with TA97a, increased the $\mathrm{His}^{+}$revertants from 142 to 449 and it was almost completely reduced to 251 (an inhibition of $72 \%)$ by PC at $500 \mu \mathrm{M}(50 \mu \mathrm{g} /$ plate). The effect was similar in TA98, TA100, and TA102 to the inhibition of mutagenicity by $71 \%, 66 \%$, and $75 \%$, respectively (Table 4 ).

The antimutagenicity of EA against promutagens BPand 2AF-induced mutagenicity was also highly significant $(P<0.005)$ as presented in Tables 5 and 6. EA showed dose dependent antimutagenic behavior against both BP and $2 \mathrm{AF}$ and reduced $\mathrm{His}^{+}$revertants by $78.6 \%$ to $88.9 \%$, respectively (Tables 5 and 6). The activity was dose dependent as determined by regression analysis between EA dose and antimutagenic response with $R^{2}$ values ranging between 0.93 and 0.99 .

EA at a dose of $500 \mu \mathrm{M}$ showed significant $(P<0.005)$ antimutagenic activity against TA97a with a decrease in mutagenicity by $72.1 \%$ followed by TA100 (65.9\%), TA98 (64.2\%), and TA102 (62.3\%) against $\mathrm{NaN}_{3}$ induced mutagenicity (Tables 7 and 8). A similar trend of activity was obtained against MMS-induced mutagenicity. The decrease in number of MMS-associated $\mathrm{His}^{+}$revertants was significant $(P<0.005)$ in TA102 (73.7\%) followed by TA98 $(69.0 \%)$, TA97a (66.5\%), and TA100 (65.3\%), as depicted in Tables 7 and 8.

3.3. PC and EA Inhibit Microsomal BP-DNA Adducts. BP $(1 \mu \mathrm{M})$ resulted in the formation of two major adducts when incubated with rat liver microsomes in the presence of stDNA (Figure 2). These adducts are products of the interaction of 9-OH-benzo[a]pyrene-4,5-epoxide and dG (adduct 1) and anti-BPDE and dG (adduct 2) [31]. No adducts were detected in DNA incubated with vehicle alone (Figure 2(a)). Incubation of $s t$-DNA with BP $(1 \mu \mathrm{M})$, microsomes, and cofactors in the presence of 20 and $40 \mu \mathrm{M}$ of PC and EA or vehicle produced qualitatively the same DNA adduct profile but the adduct levels were different. Both PC and EA inhibited BP-DNA adducts significantly. As compared with BP alone $\left(219 \pm 53\right.$ DNA adducts $/ 10^{8}$ nucleotides; $\left.n=6\right), \mathrm{PC}(42.9 \pm 16$ and $7.2 \pm 6.1$ DNA adducts $/ 10^{8}$ nucleotides) and EA (58.6 \pm 2.8 and $50.9 \pm 8.1$ DNA adducts $/ 10^{8}$ nucleotides) at 20 and $40 \mu \mathrm{M}$ concentrations, respectively, resulted in significant inhibition of BP-induced DNA adducts (Figure 2(b)).

3.4. Antiproliferative Activity of PC and EA. The antiproliferative activities of PC and EA were determined by MTT assay and presented in Figures 3(a) and 3(b). Test compounds showed significant antiproliferative activity against both lung cancer A549 and H1299 cell lines. PC and EA showed dose dependent activity against both of the cell lines after $48 \mathrm{hr}$. However, the activity of PC was somewhat better than the EA. PC demonstrated significantly high activity and inhibited $57 \%$ and $34 \%$ of $\mathrm{H} 1299$ and A549 cells at $50 \mu \mathrm{g} / \mathrm{mL}$ concentration, respectively. Similarly, at the same concentration $(50 \mu \mathrm{g} / \mathrm{mL})$, EA showed the 34 and 39 percent inhibition against H1299 and A549 lung cancer cell lines, respectively.

\section{Discussion}

Pomegranate (Punica granatum L.) fruits are widely consumed fresh and in processed forms as juice, jam, and wine 
TABLE 1: Effect of punicalagin on the 2-aminofluorene induced mutagenicity in Salmonella typhimurium.

\begin{tabular}{lccccc}
\hline \multirow{2}{*}{ Treatment } & \multirow{2}{*}{ Dose $(\mu \mathrm{M})$} & \multicolumn{3}{c}{ Number of His ${ }^{+}$revertants colonies/plate $(\mathrm{mean} \pm \mathrm{SE})$} \\
& & TA 97a & TA 98 & TA 100 & TA 102 \\
\hline Spontaneous & & $144.0 \pm 8.7$ & $39.7 \pm 3.8$ & $140.3 \pm 10.8$ & $325.7 \pm 16.6$ \\
Positive control (2AF) & $1.5 \mu \mathrm{g}$ & $336.7 \pm 14.4$ & $254.0 \pm 11.8$ & $510.3 \pm 23.9$ & $1475.0 \pm 38.1$ \\
& 50 & $132.3 \pm 8.8$ & $40.7 \pm 2.9$ & $136.0 \pm 11.7$ & $320.0 \pm 21.9$ \\
& 100 & $158.0 \pm 7.4$ & $36.3 \pm 1.8$ & $162.7 \pm 15.0$ & $341.0 \pm 18.3$ \\
& 250 & $165.7 \pm 10.9$ & $31.0 \pm 1.7$ & $175.3 \pm 14.3$ & $356.0 \pm 10.4$ \\
${ }^{a}$ Punicalagin & 500 & $188.0 \pm 9.5$ & $22.3 \pm 1.8$ & $191.0 \pm 15.0$ & $358.0 \pm 19.9$ \\
& 50 & $304.7 \pm 19.8(15.7)$ & $210.3 \pm 10.7(20.5)$ & $426.7 \pm 28.3(22.4)$ & $1028.0 \pm 21.8^{* * *}(38.7)$ \\
& 100 & $270.3 \pm 10.1^{*}(37.1)$ & $172.3 \pm 12.0^{* *}(37.5)$ & $358.0 \pm 12.2^{* *}(43.8)$ & $854.0 \pm 31.6^{* * *}(54.8)$ \\
& 250 & $246.7 \pm 12.3^{* *}(52.6)$ & $122.0 \pm 9.9^{* *}(59.2)$ & $304.3 \pm 19.5^{* *}(61.5)$ & $660.0 \pm 24.7^{* * *}(72.8)$ \\
${ }^{b}$ Punicalagin $+2 \mathrm{AF}$ & 500 & $220.0 \pm 9.3^{* * *}(78.5)$ & $65.3 \pm 4.1^{* * *}(81.4)$ & $245.0 \pm 9.6^{* * *}(83.1)$ & $563.0 \pm 29.4^{* * *}(81.6)$ \\
\hline$R^{2}$ & & 0.98 & 0.99 & 0.99 & 0.99 \\
\hline
\end{tabular}

${ }^{\mathrm{a}}$ Negative control; ${ }^{\mathrm{b}}$ preincubation test; values in parenthesis are \% inhibition of mutagenicity.

${ }^{*} P<0.05 ;{ }^{* *} P<0.005$ and ${ }^{* * *} P<0.001 ; 2 \mathrm{AF}$ : 2 -aminofluorene; $R^{2}$ : linear regression analysis.

TABLE 2: Effect of punicalagin on the benzo[a]pyrene induced mutagenicity in Salmonella typhimurium.

\begin{tabular}{lccccc}
\hline \multirow{2}{*}{ Treatment } & Dose $(\mu \mathrm{M})$ & \multicolumn{4}{c}{ Number of His ${ }^{+}$revertants colonies/plate $(\mathrm{mean} \pm$ SE) } \\
& & TA 97a & TA 98 & TA 100 & TA 102 \\
\hline Spontaneous & & $144.0 \pm 8.7$ & $39.7 \pm 3.8$ & $140.3 \pm 10.8$ & $325.7 \pm 16.6$ \\
Positive control (BP) & $1.5 \mu \mathrm{g}$ & $736.7 \pm 30.1$ & $165.7 \pm 10.2$ & $704.3 \pm 27.0$ & $694.0 \pm 20.8$ \\
& 50 & $132.3 \pm 8.8$ & $40.7 \pm 2.9$ & $136.0 \pm 11.7$ & $320.0 \pm 21.9$ \\
& 100 & $158.0 \pm 7.4$ & $36.3 \pm 1.8$ & $162.7 \pm 15.0$ & $341.0 \pm 18.3$ \\
Punicalagin & 250 & $165.7 \pm 10.9$ & $31.0 \pm 1.7$ & $175.3 \pm 14.3$ & $356.0 \pm 10.4$ \\
& 500 & $188.0 \pm 9.5$ & $22.3 \pm 1.8$ & $191.0 \pm 15.0$ & $358.0 \pm 19.9$ \\
& 50 & $645.3 \pm 28.7(15.1)$ & $138.0 \pm 8.7(22.1)$ & $530.3 \pm 26.4^{* *}(30.6)$ & $635.0 \pm 23.0(15.8)$ \\
& 100 & $538.3 \pm 28.9^{* *}(34.3)$ & $105.3 \pm 9.0^{*}(46.6)$ & $442.7 \pm 31.4^{* *}(48.3)$ & $595.0 \pm 28.8^{*}(28.0)$ \\
Punicalagin + BP & 250 & $431.0 \pm 18.4^{* * *}(53.5)$ & $65.0 \pm 6.8^{* *}(74.8)$ & $366.0 \pm 20.2^{* * *}(64.0)$ & $496.0 \pm 17.4^{* *}(58.6)$ \\
& 500 & $316.0 \pm 17.6^{* * *}(76.7)$ & $52.7 \pm 4.3^{* *}(78.8)$ & $270.7 \pm 15.6^{* * *}(84.5)$ & $438.0 \pm 19.5^{* * *}(76.2)$ \\
\hline$R^{2}$ & & 0.99 & 0.94 & 0.99 & 0.99 \\
\hline
\end{tabular}

${ }^{a}$ Negative control; ${ }^{b}$ preincubation test; values in parenthesis are $\%$ inhibition of mutagenicity.

${ }^{*} P<0.05 ;{ }^{* *} P<0.005$ and ${ }^{* * *} P<0.001$; BP: benzo[a]pyrene; $R^{2}$ : linear regression analysis.

TABLE 3: Effect of punicalagins on the sodium azide induced mutagenicity in Salmonella typhimurium.

\begin{tabular}{lccccc}
\hline \multirow{2}{*}{ Treatment } & Dose $(\mu \mathrm{M})$ & \multicolumn{3}{c}{ Number of His ${ }^{+}$revertants colonies/plate $(\mathrm{mean} \pm \mathrm{SE})$} \\
& & TA 97a & TA 98 & TA 100 & TA 102 \\
\hline Spontaneous & & $142.0 \pm 5.3$ & $33.7 \pm 2.0$ & $128.3 \pm 4.9$ & $240.7 \pm 7.0$ \\
Positive control $\left(\mathrm{NaN}_{3}\right)$ & $1.5 \mu \mathrm{g}$ & $256.0 \pm 11.7$ & $52.3 \pm 1.8$ & $361.3 \pm 11.0$ & $370.0 \pm 9.0$ \\
& 50 & $141.3 \pm 5.2$ & $42.3 \pm 1.8$ & $189.7 \pm 12.0$ & $306.7 \pm 13.3$ \\
& 100 & $153.7 \pm 9.2$ & $35.7 \pm 1.8$ & $181.0 \pm 7.4$ & $275.3 \pm 22.1$ \\
Punicalagin & 250 & $158.3 \pm 7.1$ & $30.0 \pm 1.2$ & $165.3 \pm 5.4$ & $250.0 \pm 22.9$ \\
& 500 & $174.0 \pm 6.4$ & $27.3 \pm 2.0$ & $187.7 \pm 9.8$ & $231.7 \pm 24.8$ \\
& 50 & $244.3 \pm 6.7(10.2)$ & $51.0 \pm 1.7(13.3)$ & $342.0 \pm 4.7(11.3)$ & $346.3 \pm 23.5(18.0)$ \\
& 100 & $221.0 \pm 7.1(34.2)$ & $47.3 \pm 1.8(30.0)$ & $301.7 \pm 7.8^{*}(33.1)$ & $341.0 \pm 19.1(17.6)$ \\
Punicalagin $+\mathrm{NaN}_{3}$ & 250 & $202.3 \pm 8.7^{*}(54.9)$ & $40.7 \pm 2.6^{*}(52.2)$ & $254.3 \pm 10.8^{* *}(54.6)$ & $310.7 \pm 16.0^{*}(42.2)$ \\
& 500 & $195.0 \pm 10.8^{*}(74.4)$ & $36.0 \pm 1.7^{* *}(65.3)$ & $232.3 \pm 9.4^{* * *}(74.3)$ & $381.3 \pm 17.6^{* *}(59.8)$ \\
\hline$R^{2}$ & & 0.99 & 0.99 & 0.99 & 0.91 \\
\hline
\end{tabular}

${ }^{\mathrm{a}}$ Negative control; ${ }^{\mathrm{b}}$ preincubation test; values in parenthesis are $\%$ inhibition of mutagenicity.

${ }^{*} P<0.05 ;{ }^{* *} P<0.005$ and ${ }^{* * *} P<0.001 ; \mathrm{NaN}_{3}$ : sodium azide; $R^{2}$ : linear regression analysis. 
TABLE 4: Effect of punicalagins on the methyl methanesulfonate induced mutagenicity in Salmonella typhimurium.

\begin{tabular}{lccccc}
\hline \multirow{2}{*}{ Treatment } & Dose $(\mu \mathrm{M})$ & \multicolumn{3}{c}{ Number of His ${ }^{+}$revertants colonies/plate $(\mathrm{mean} \pm$ SE) } \\
& & TA 97a & TA 98 & TA 100 & TA 102 \\
\hline Spontaneous & & $142.0 \pm 5.3$ & $33.7 \pm 2.0$ & $128.3 \pm 4.9$ & $240.7 \pm 7.0$ \\
Positive control (MMS) & $1.0 \mu \mathrm{g}$ & $449.7 \pm 7.2$ & $53.7 \pm 1.5$ & $963.0 \pm 11.4$ & $1237.0 \pm 14.5$ \\
& 50 & $141.3 \pm 5.2$ & $42.3 \pm 1.8$ & $189.7 \pm 12.0$ & $292.0 \pm 7.7$ \\
& 100 & $153.7 \pm 9.2$ & $35.7 \pm 1.8$ & $181.0 \pm 7.4$ & $278.0 \pm 12.8$ \\
Punicalagin & 250 & $158.3 \pm 7.1$ & $30.0 \pm 1.2$ & $165.3 \pm 5.4$ & $255.0 \pm 13.2$ \\
& 500 & $174.0 \pm 6.4$ & $27.3 \pm 2.0$ & $187.7 \pm 9.8$ & $254.0 \pm 14.3$ \\
& 50 & $418.3 \pm 11.7(10.2)$ & $50.3 \pm 1.8(29.4)$ & $856.3 \pm 13.1^{* *}(13.8)$ & $1072.0 \pm 10.7^{* *}(17.5)$ \\
& 100 & $390.7 \pm 10.2^{* *}(19.9)$ & $45.3 \pm 2.0^{*}(46.3)$ & $722.0 \pm 15.0^{* * *}(30.8)$ & $942.0 \pm 16.2^{* * *}(30.8)$ \\
Punicalagin + MMS & 250 & $326.0 \pm 7.8^{* * *}(42.4)$ & $39.7 \pm 2.0^{* *}(59.2)$ & $601.3 \pm 12.3^{* * *}(45.3)$ & $738.0 \pm 14.8^{* * *}(50.8)$ \\
& 500 & $251.0 \pm 9.0^{* * *}(72.1)$ & $35.0 \pm 2.1^{* *}(70.9)$ & $451.7 \pm 15.6^{* * *}(66.0)$ & $509.0 \pm 19.7^{* * *}(74.1)$ \\
\hline$R^{2}$ & & 0.95 & 0.99 & 0.99 & 0.99 \\
\hline
\end{tabular}

${ }^{a}$ Negative control; ${ }^{b}$ preincubation test; values in parenthesis are $\%$ inhibition of mutagenicity.

${ }^{*} P<0.05 ;{ }^{* *} P<0.005$ and ${ }^{* * *} P<0.001$; MMS: methyl methanesulfonate; $R^{2}$ : linear regression analysis.

TABLE 5: Effect of ellagic acid on the 2-aminofluorene induced mutagenicity in Salmonella typhimurium.

\begin{tabular}{|c|c|c|c|c|c|}
\hline \multirow{2}{*}{ Treatment } & \multirow{2}{*}{ Dose $(\mu \mathrm{M})$} & \multicolumn{4}{|c|}{ Number of $\mathrm{His}^{+}$revertants colonies/plate $($mean $\pm \mathrm{SE})$} \\
\hline & & TA 97a & TA 98 & TA 100 & TA 102 \\
\hline Spontaneous & & $144.0 \pm 8.7$ & $39.7 \pm 3.8$ & $140.3 \pm 10.8$ & $325.7 \pm 16.6$ \\
\hline Positive control (2AF) & $1.5 \mu \mathrm{g}$ & $336.7 \pm 14.4$ & $254.0 \pm 11.8$ & $510.3 \pm 23.9$ & $1475.0 \pm 38.1$ \\
\hline \multirow{4}{*}{${ }^{\mathrm{a}}$ Ellagic acid } & 50 & $142.3 \pm 10.7$ & $50.0 \pm 5.1$ & $136.3 \pm 12.0$ & $336.0 \pm 23.0$ \\
\hline & 100 & $159.7 \pm 10.5$ & $44.7 \pm 3.8$ & $162.7 \pm 16.6$ & $275.0 \pm 16.8$ \\
\hline & 250 & $175.0 \pm 15.0$ & $38.3 \pm 2.3$ & $178.0 \pm 12.7$ & $308.0 \pm 17.2$ \\
\hline & 500 & $184.0 \pm 10.6$ & $32.0 \pm 3.6$ & $188.7 \pm 12.8$ & $302.0 \pm 17.1$ \\
\hline \multirow{4}{*}{${ }^{\mathrm{b}}$ Ellagic acid $+2 \mathrm{AF}$} & 50 & $312.3 \pm 20.5(12.5)$ & $214.3 \pm 13.9(19.4)$ & $426.0 \pm 18.6^{*}(22.5)$ & $1276.0 \pm 38.0^{*}(17.5)$ \\
\hline & 100 & $296.7 \pm 13.4(22.6)$ & $171.0 \pm 9.5^{* *}(39.6)$ & $350.0 \pm 12.8^{* *}(46.1)$ & $924.0 \pm 25.3^{* * *}(45.9)$ \\
\hline & 250 & $264.0 \pm 14.2^{*}(44.9)$ & $132.7 \pm 9.3^{* *}(56.3)$ & $285.3 \pm 13.1^{* *}(67.7)$ & $610.0 \pm 26.2^{* * *}(74.1)$ \\
\hline & 500 & $212.0 \pm 10.4^{* *}(81.7)$ & $76.3 \pm 6.1^{* * *}(80.0)$ & $240.7 \pm 9.8^{* * *}(83.8)$ & $431.0 \pm 13.6^{* * *}(89.0)$ \\
\hline$R^{2}$ & & 0.93 & 0.99 & 0.99 & 0.98 \\
\hline
\end{tabular}

${ }^{\mathrm{a}}$ Negative control; ${ }^{\mathrm{b}}$ preincubation test; values in parenthesis are $\%$ inhibition of mutagenicity.

${ }^{*} P<0.05 ;{ }^{* *} P<0.005$ and ${ }^{* * *} P<0.001 ; 2 \mathrm{AF}$ : 2 -aminofluorene; $R^{2}$ : linear regression analysis.

TABLE 6: Effect of ellagic acid on the benzo[a]pyrene induced mutagenicity in Salmonella typhimurium.

\begin{tabular}{lccccc}
\hline \multirow{2}{*}{ Treatment } & \multirow{2}{*}{ Dose $(\mu \mathrm{M})$} & \multicolumn{4}{c}{ Number of His ${ }^{+}$revertants colonies/plate $(\mathrm{mean} \pm$ SE) } \\
& & TA 97a & TA 98 & TA 100 & TA 102 \\
\hline Spontaneous & & $144.0 \pm 8.7$ & $39.7 \pm 3.8$ & $140.3 \pm 10.8$ & $325.7 \pm 16.6$ \\
Positive control (BP) & $1.5 \mu \mathrm{g}$ & $736.7 \pm 30.1$ & $165.7 \pm 10.2$ & $704.3 \pm 27.0$ & $694.0 \pm 20.8$ \\
& 50 & $142.3 \pm 10.7$ & $50.0 \pm 5.1$ & $136.3 \pm 12.0$ & $336.0 \pm 23.0$ \\
& 100 & $159.7 \pm 10.5$ & $44.7 \pm 3.8$ & $162.7 \pm 16.6$ & $275.0 \pm 16.8$ \\
${ }^{a}$ Ellagic acid & 250 & $175.0 \pm 15.0$ & $38.3 \pm 2.3$ & $178.0 \pm 12.7$ & $308.0 \pm 17.2$ \\
& 500 & $184.0 \pm 10.6$ & $32.0 \pm 3.6$ & $188.7 \pm 12.8$ & $302.0 \pm 17.1$ \\
& 50 & $652.7 \pm 35.3(14.1)$ & $140.0 \pm 12.2(22.2)$ & $580.3 \pm 25.6^{*}(21.8)$ & $653.0 \pm 34.7(11.5)$ \\
& 100 & $529.0 \pm 28.6^{* *}(36.0)$ & $107.3 \pm 7.9^{*}(48.2)$ & $472.3 \pm 19.4^{* *}(42.8)$ & $595.0 \pm 24.1^{*}(23.6)$ \\
${ }^{b}$ Ellagic acid + BP & 250 & $333.3 \pm 22.2^{* * *}(71.8)$ & $86.3 \pm 5.8^{* *}(62.3)$ & $336.0 \pm 17.6^{* * *}(70.0)$ & $514.0 \pm 21.4^{* *}(46.6)$ \\
& 500 & $275.3 \pm 17.5^{* * *}(83.5)$ & $60.7 \pm 10.5^{* *}(78.6)$ & $245.7 \pm 14.4^{* * *}(88.9)$ & $366.0 \pm 25.0^{* * *}(83.7)$ \\
\hline$R^{2}$ & & 098 & 0.97 & 0.99 & 0.93 \\
\hline
\end{tabular}

${ }^{\mathrm{a}}$ Negative control; ${ }^{\mathrm{b}}$ preincubation test; values in parenthesis are $\%$ inhibition of mutagenicity.

${ }^{*} P<0.05 ;{ }^{* *} P<0.005$ and ${ }^{* * *} P<0.001 ; \mathrm{B}[\mathrm{a}] \mathrm{P}$ : benzo[a]pyrene; $R^{2}$ : linear regression analysis. 
TABLE 7: Effect of ellagic acid on the sodium azide induced mutagenicity in Salmonella typhimurium.

\begin{tabular}{|c|c|c|c|c|c|}
\hline \multirow{2}{*}{ Treatment } & \multirow{2}{*}{ Dose $(\mu \mathrm{M})$} & \multicolumn{4}{|c|}{ Number of $\mathrm{His}^{+}$revertants colonies/plate (mean $\pm \mathrm{SE}$ ) } \\
\hline & & TA $97 \mathrm{a}$ & TA 98 & TA 100 & TA 102 \\
\hline Spontaneous & & $142.0 \pm 5.3$ & $33.7 \pm 2.0$ & $128.3 \pm 4.9$ & $240.7 \pm 12.1$ \\
\hline Positive control $\left(\mathrm{NaN}_{3}\right)$ & $1.5 \mu \mathrm{g}$ & $256.0 \pm 11.7$ & $52.3 \pm 1.8$ & $361.3 \pm 11.0$ & $355.0 \pm 15.5$ \\
\hline \multirow{4}{*}{${ }^{a}$ Ellagic acid } & 50 & $189.7 \pm 6.4$ & $50.7 \pm 1.5$ & $179.7 \pm 0.1$ & $310.7 \pm 27.0$ \\
\hline & 100 & $163.0 \pm 5.2$ & $38.0 \pm 1.7$ & $170.0 \pm 5.7$ & $288.0 \pm 21.0$ \\
\hline & 250 & $145.3 \pm 4.3$ & $34.3 \pm 2.4$ & $155.7 \pm 10.3$ & $262.3 \pm 13.2$ \\
\hline & 500 & $134.0 \pm 3.8$ & $30.0 \pm 1.2$ & $132.3 \pm 8.6$ & $248.0 \pm 19.1$ \\
\hline \multirow{4}{*}{${ }^{\mathrm{b}}$ Ellagic acid $+\mathrm{NaN}_{3}$} & 50 & $242.0 \pm 11.8(21.1)$ & $52.0 \pm 1.7(20.0)$ & $340.7 \pm 9.4(11.4)$ & $345.3 \pm 26.7(21.9)$ \\
\hline & 100 & $219.3 \pm 7.1(39.4)$ & $48.3 \pm 2.7(27.9)$ & $312.3 \pm 8.4^{*}(25.6)$ & $328.0 \pm 28.2(40.3)$ \\
\hline & 250 & $196.7 \pm 8.2^{*}(53.6)$ & $43.3 \pm 2.6^{*}(50.0)$ & $266.0 \pm 7.8^{* *}(46.4)$ & $308.0 \pm 23.6^{*}(50.7)$ \\
\hline & 500 & $168.0 \pm 7.0^{* *}(72.1)$ & $38.0 \pm 1.7^{* *}(64.2)$ & $210.3 \pm 12.4^{* * *}(65.9)$ & $288.3 \pm 19.2^{* *}(62.3)$ \\
\hline$R^{2}$ & & 0.99 & 0.98 & 0.99 & 0.97 \\
\hline
\end{tabular}

${ }^{a}$ Negative control; ${ }^{b}$ preincubation test; values in parenthesis are $\%$ inhibition of mutagenicity.

${ }^{*} P<0.05 ;{ }^{* *} P<0.005$ and ${ }^{* * *} P<0.001 ; \mathrm{NaN}_{3}$ : sodium azide; $R^{2}$ : linear regression analysis.

TABLE 8: Effect of ellagic acid on the methyl methanesulfonate induced mutagenicity in Salmonella typhimurium.

\begin{tabular}{lccccc}
\hline \multirow{2}{*}{ Treatment } & Dose $(\mu \mathrm{M})$ & \multicolumn{4}{c}{ Number of His ${ }^{+}$revertants colonies/plate $(\mathrm{mean} \pm$ SE) } \\
& & TA 97a & TA 98 & TA 100 & TA 102 \\
\hline Spontaneous & & $142.0 \pm 5.3$ & $33.7 \pm 2.0$ & $128.3 \pm 4.9$ & $240.7 \pm 7.0$ \\
Positive control (MMS) & $1.5 \mu \mathrm{g}$ & $449.7 \pm 7.2$ & $53.7 \pm 1.5$ & $963.0 \pm 11.4$ & $1237.0 \pm 14.5$ \\
& 50 & $189.7 \pm 6.4$ & $50.7 \pm 1.5$ & $179.7 \pm 9.1$ & $338.0 \pm 15.6$ \\
& 100 & $163.0 \pm 5.2$ & $38.0 \pm 1.7$ & $170.0 \pm 5.7$ & $311.0 \pm 12.1$ \\
${ }^{a}$ Ellagic acid & 250 & $145.3 \pm 4.3$ & $34.3 \pm 2.4$ & $155.7 \pm 10.3$ & $274.0 \pm 7.6$ \\
& 500 & $134.0 \pm 3.8$ & $30.0 \pm 1.2$ & $132.3 \pm 8.6$ & $228.0 \pm 11.0$ \\
& 50 & $426.3 \pm 11.6(9.0)$ & $53.0 \pm 1.2(22.2)$ & $900.3 \pm 16.3^{*}(8.0)$ & $1071.0 \pm 16.7^{* *}(18.5)$ \\
& 100 & $378.0 \pm 10.8^{* *}(25.0)$ & $48.3 \pm 2.0(34.0)$ & $754.0 \pm 8.2^{* * *}(26.4)$ & $956.0 \pm 19.6^{* * *}(30.3)$ \\
${ }^{b}$ Ellagic acid + MMS & 250 & $321.3 \pm 10.8^{* * *}(42.2)$ & $44.0 \pm 2.1^{*}(50.0)$ & $598.7 \pm 14.2^{* * *}(45.1)$ & $810.0 \pm 19.1^{* * *}(44.3)$ \\
& 500 & $239.7 \pm 10.8^{* * *}(66.5)$ & $37.3 \pm 2.6^{* *}(69.0)$ & $420.3 \pm 6.9^{* * *}(65.3)$ & $506.0 \pm 13.5^{* * *}(72.4)$ \\
\hline$R^{2}$ & & 0.98 & 0.99 & 0.99 & 0.95 \\
\hline
\end{tabular}

${ }^{\mathrm{a}}$ Negative control; ${ }^{\mathrm{b}}$ preincubation test; values in parenthesis are \% inhibition of mutagenicity.

${ }^{*} P<0.05 ;{ }^{* *} P<0.005$ and ${ }^{* * *} P<0.001$; MMS: methyl methanesulfonate; $R^{2}$ : linear regression analysis.

and have been shown to have various protective effects. We have shown that the methanol extract of Punica granatum fruit peel possesses antimutagenic, antioxidant, DNA protective, and antiproliferative activity $[15,19]$. The husk of pomegranate is rich in ellagitannins (ETs) such as PC, punicalin, gallagic acid, EA, and EA-glycosides [18]. In the present study, PC and one of its hydrolysed products EA were tested for their protective effects against BP-induced DNA adducts and on the genotoxicity induced by various mutagents and promutagens by Ames test. Ames assay serves as a quick and convenient assay to estimate the antimutagenic potential of a compound which is also prescreening of anticancer compounds because standard assays on mice and rats are timeconsuming and expensive. Standard mutagens/carcinogens used in this study were well-established mutagens in Ames test.

In our study, none of the tested compounds exhibited any mutagenic effect in the Ames test in the absence of enzymatic metabolism. This suggests that DNA does not seem to be a relevant target for PC and EA, and it did not produce DNA lesions that block DNA synthesis, leading to the induction of the SOS system [32]. A variety of mechanisms can play a vital role in antimutagenic and anticarcinogenic activity of phytocompounds. These mechanisms include inhibition of cell proliferation, signal transduction modulation, scavenging of free radicals, induction of detoxification enzymes, induction of cell-cycle arrest and apoptosis, modulation of cytoskeletal proteins that play a key role in mitosis, and the inhibition of topoisomerase I or II activity [33].

In the Ames test, PC and EA showed antimutagenicity $(P \leq 0.05)$ against mutagens and promutagens in the presence of S9. Since these bacterial strains are unable to metabolize BP and 2AF, to an appreciable extent, a metabolizing system of liver homogenate from Aroclor induced rats (S9) is included in the assay that has been shown to produce a number of reactive intermediates like BP-4,5-oxide and 


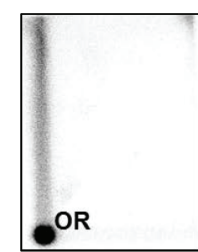

Vehicle

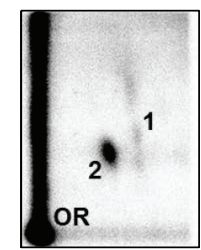

$\mathrm{BP}+\mathrm{PC}$

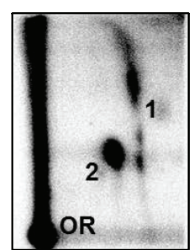

BP

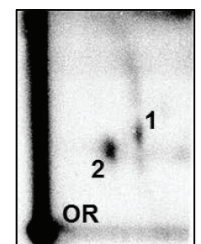

$\mathrm{BP}+\mathrm{EA}$

(a)

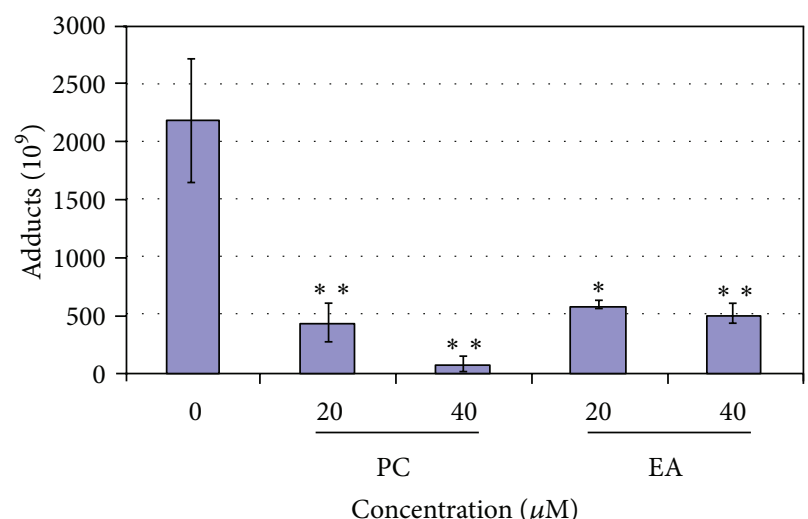

(b)

FIGURE 2: (a) Representative autoradiographs of ${ }^{32} \mathrm{P}$-postlabelling analysis of microsomal-benzo[a]pyrene (BP) DNA adducts in the presence of vehicle alone (2\% DMSO), BP $(1 \mu \mathrm{M})+$ vehicle, $\mathrm{BP}(1 \mu \mathrm{M})+$ punicalagin $(\mathrm{PC})(40 \mu \mathrm{M})$, and $\mathrm{BP}(1 \mu \mathrm{M})+$ ellagic acid (EA) $(40 \mu \mathrm{M})$. Adduct 1, anti-benzo[a]pyrene-7,8-diol-9,10-epoxide-dG, and adduct 2, 9-OH-benzo[a]pyrene-4,5-epoxide-dG. PC and EA alone group were not included since we do not expect any background BP-DNA adduct. OR, origin. (b) Inhibition of microsomal BP-induced DNA adducts by $\mathrm{PC}$ and EA. DNA adducts were analyzed by ${ }^{32} \mathrm{P}$-postlabeling assay. Data represent an average \pm standard error of $4-6$ samples. ${ }^{* *} \mathrm{P}<0.01$; ${ }^{*} P<0.05$. Part of the figure is reprinted from Mutat. [28] Copyright (2014), with permission from Elsevier.

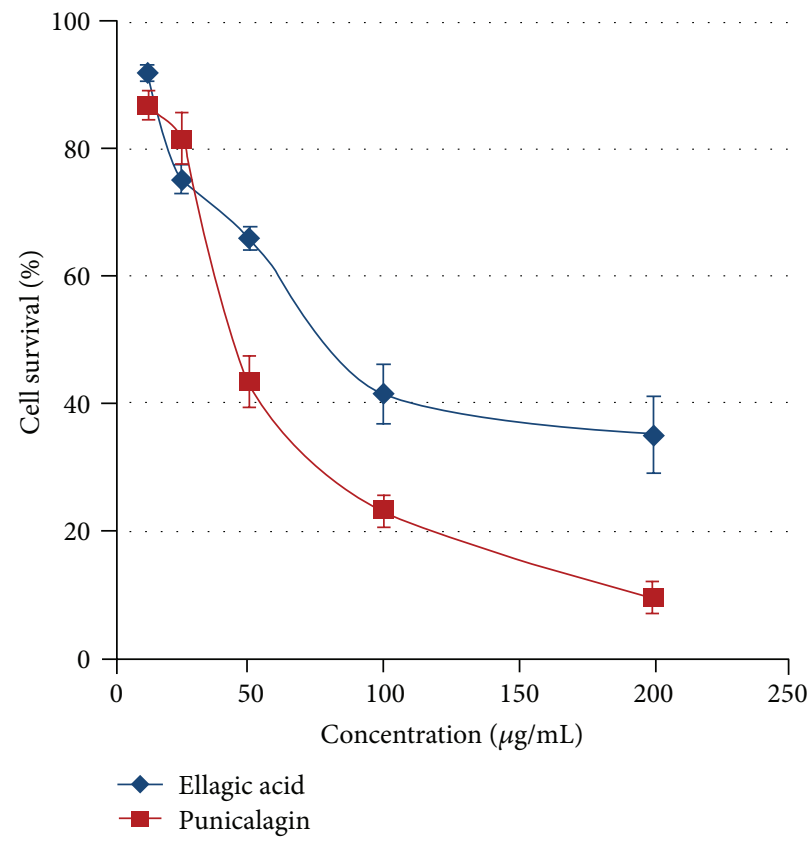

(a)

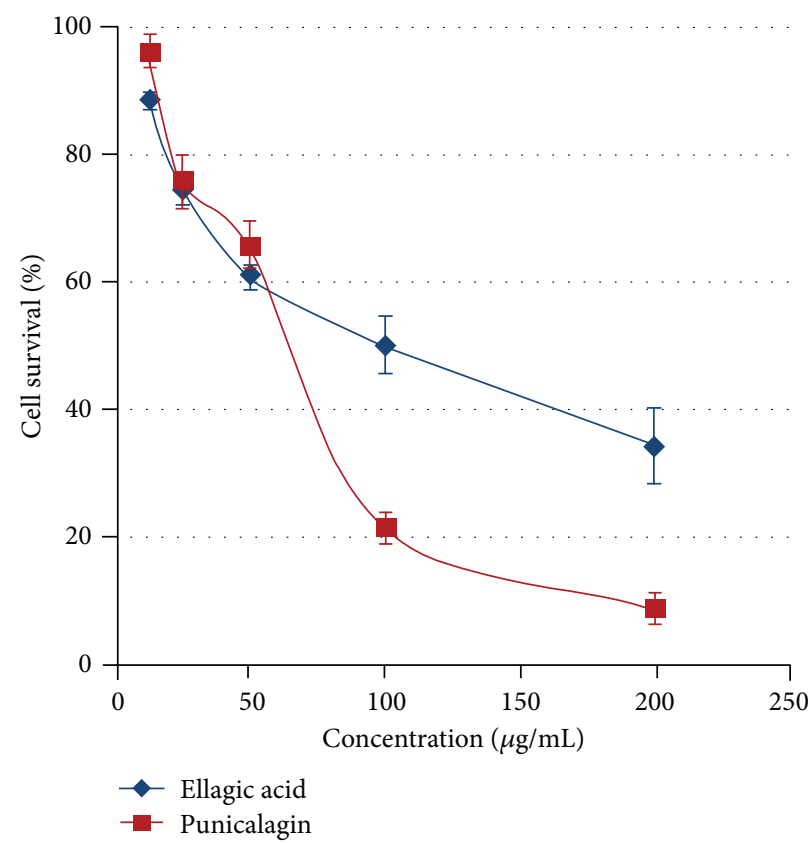

(b)

FIGURE 3: Antiproliferative activity of PC and EA against lung cancer H1299 (a) and A549 (b) cells. Cells were treated with either vehicle or PC and EA at $12.5-200 \mu \mathrm{g} / \mathrm{mL}$ concentrations for $48 \mathrm{~h}$. Data are expressed as percentage of untreated cells, mean \pm SD $(n=3)$.

9-hydroxy-BP-4,5-oxide from BP [34]. The antimutagenic effects of PC and EA could also be due to inhibitory effect against the tested mutagens.

Similarly, the inhibitory activity in the preincubation experiments against $2 \mathrm{AF}$-induced mutagenicity implies that the added modulator interfered with the metabolic activation of the promutagen or tends to interact directly with the ultimate mutagenic metabolite. Cytochrome P-450 enzyme system catalyses the formation of $\mathrm{N}$-hydroxy derivative, that is, N-hydroxy-2-aminoflourene which probably interacts directly with DNA [35]. Thus, the alteration in the structure and function of P-450 enzyme may result in altered rates and 
differential pathways of metabolism of mutagens and carcinogens and in some cases provide protection against chemically induced mutagenesis. We have recently demonstrated that, besides effect on CYP1A1 and induction of glutathione, PC can inhibit BP by direct inhibition. Moreover, PC upon hydrolysis releases its active metabolite EA, which has been shown to protect DNA by covalently binding [28].

DNA adduct formation represents a net effect of activation and detoxification processes and can be used to determine efficacy of chemopreventive agents. In this study, efficacy of PC and EA was determined by its ability in reducing $\mathrm{BP}$-induced DNA adducts in vitro. $\mathrm{PC}$ and $\mathrm{EA}$ were found to inhibit both anti-BP-7,8-diol-9,10-epoxide-dG and 9-OH-benzo[a]pyrene-4,5-epoxide-dG. However, inhibition of anti-BPDE adduct by PC was more pronounced.

Two major pathways can be involved in the inhibition of BP-induced DNA adducts (i) by inhibiting the P450 activity and/or enhancement of phase II enzymes and (ii) by direct conjugation with anti-BPDE. It has been previously demonstrated that PC does inhibit anti-BPDE-induced DNA adducts and thus ruled out the scavenging of anti-BPDE. However, EA has been shown to covalently interact with antiBPDE through its catechol groups as determined by HPLC [36]. Therefore, it is likely that PC is indirectly involved in scavenging anti-BPDE through its catechol containing moieties, ellagic acid, and gallic acid. Apparently, the catechol moieties of these constituents were protected in the conjugated PC complex.

This study showed the high antiproliferative activity of PC and EA. Both of the lung cancer cell lines A549 and H1299 showed almost similar level of sensitivity to the tested compounds. The antiproliferative activity of PC and EA against oral, colon, and prostate cancer cell lines has been previously demonstrated [17]. In another study, both PC and EA were found to induce apoptosis via mitochondrial pathway in colon cancer Caco- 2 cells but not in normal colon cells. EA arrest the cell cycle in S phase through downregulation of cyclins $\mathrm{A}$ and $\mathrm{B} 1$ and up-regulation of cyclin $\mathrm{E}$. It also induces apoptosis via intrinsic pathway through Bcl-XL downregulation, mitochondrial release of cytochrome $\mathrm{C}$, and activation of initiator caspase 9 and effector caspase 3 [37]. Thus, our data corroborates with the literature [17] and clearly demonstrates the antiproliferative potential of PC and EA.

In summary, the data obtained in the present study clearly demonstrated that PC and EA are the major active constituents of pomegranate with promising antimutagenic and protective against DNA damage. Further, these studies demonstrate, for the first time, that both PC and EA possess almost similar level of antimutagenic properties against a variety of mutagens and could be a viable candidate for the future anticancer drugs.

\section{Conflict of Interests}

The authors declare that there is no conflict of interests regarding the publication of this paper.

\section{Acknowledgments}

The authors are thankful to the UGC, New Delhi, for financial assistance in the form of research fellowship to Maryam Zahin through AMU, Aligarh, India. This work was partially supported from Agnes Brown Duggan Endowment fund. Dr. Ramesh Gupta holds the Agnes Brown Duggan Chair in Oncological Research. The authors also thank Dr. Manicka V. Vadhanam for useful discussion during preparation of the paper.

\section{References}

[1] J. M. C. Gutteridge, "Invited review. Free radicals in disease processes: a compilation of cause and consequence," Free Radical Research Communications, vol. 19, no. 3, pp. 141-158, 1993.

[2] M. Valko, D. Leibfritz, J. Moncol, M. T. D. Cronin, M. Mazur, and J. Telser, "Free radicals and antioxidants in normal physiological functions and human disease," International Journal of Biochemistry and Cell Biology, vol. 39, no. 1, pp. 44-84, 2007.

[3] R. Govindarajan, M. Vijayakumar, and P. Pushpangadan, "Antioxidant approach to disease management and the role of "Rasayana" herbs of Ayurveda," Journal of Ethnopharmacology, vol. 99, no. 2, pp. 165-178, 2005.

[4] W. M. El-Sayed and W. A. Hussin, "Antimutagenic and antioxidant activity of novel 4-substituted phenyl-2, 2' -bichalcophenes and aza-analogs," Journal of Drug Design, Development and Therapy, vol. 7, pp. 73-81, 2013.

[5] A. Cardador-Martínez, A. Albores, M. Bah et al., "Relationship among antimutagenic, antioxidant and enzymatic activities of methanolic extract from common beans (Phaseolus vulgaris $\mathrm{L}$ )," Plant Foods for Human Nutrition, vol. 61, no. 4, pp. 161-168, 2006.

[6] K. Hemminki, "DNA adducts, mutations and cancer," Carcinogenesis, vol. 14, no. 10, pp. 2007-2012, 1993.

[7] K. Hemminki, M. Koskinen, H. Rajaniemi, and C. Zhao, "DNA adducts, mutations, and cancer 2000," Regulatory Toxicology and Pharmacology, vol. 32, no. 3, pp. 264-275, 2000.

[8] D. H. Phillips, "DNA adducts in human tissues: biomarkers of exposure to carcinogens in tobacco smoke," Environmental Health Perspectives, vol. 104, supplement 3, pp. 453-458, 1996.

[9] L. A. Loeb and C. C. Harris, "Advances in chemical carcinogenesis: a historical review and prospective," Cancer Research, vol. 68, no. 17, pp. 6863-6872, 2008.

[10] R. W. L. Godschalk, F.-J. van Schooten, and H. Bartsch, "A critical evaluation of DNA adducts as biological markers for human exposure to polycyclic aromatic compounds," Journal of Biochemistry and Molecular Biology, vol. 36, no. 1, pp. 1-11, 2003.

[11] L. R. Ferguson, "Antimutagens as cancer chemopreventive agents in the diet," Mutation Research: Fundamental and Molecular Mechanisms of Mutagenesis, vol. 307, no. 1, pp. 395-410, 1994.

[12] M. Green, R. Thomas, L. Gued, and S. Sadrud-Din, "Inhibition of DES-induced DNA adducts by diallyl sulfide: implications in liver cancer prevention," Oncology Reports, vol. 10, no. 3, pp. 767-771, 2003.

[13] F. Aqil, M. Zahin, and I. Ahmad, "Antimutagenic activity of methanolic extracts of four ayurvedic medicinal plants," Indian Journal of Experimental Biology, vol. 46, no. 9, pp. 668-672, 2008. 
[14] M. Khader, N. Bresgen, and P. M. Eckl, "Antimutagenic effects of ethanolic extracts from selected Palestinian medicinal plants," Journal of Ethnopharmacology, vol. 127, no. 2, pp. 319-324, 2010.

[15] M. Zahin, F. Aqil, and I. Ahmad, "Broad spectrum antimutagenic activity of antioxidant active fraction of Punica granatum L. peel extracts," Mutation Research: Genetic Toxicology and Environmental Mutagenesis, vol. 703, no. 2, pp. 99-107, 2010.

[16] F. Aqil and I. Ahmad, "Antibacterial properties of traditionally used Indian medicinal plants," Methods and Findings in Experimental and Clinical Pharmacology, vol. 29, no. 2, pp. 79-92, 2007.

[17] N. P. Seeram, L. S. Adams, S. M. Henning et al., "In vitro antiproliferative, apoptotic and antioxidant activities of punicalagin, ellagic acid and a total pomegranate tannin extract are enhanced in combination with other polyphenols as found in pomegranate juice," Journal of Nutritional Biochemistry, vol. 16, no. 6, pp. 360-367, 2005.

[18] N. Seeram, R. Lee, M. Hardy, and D. Heber, "Rapid large scale purification of ellagitannins from pomegranate husk, a by-product of the commercial juice industry," Separation and Purification Technology, vol. 41, no. 1, pp. 49-55, 2005.

[19] F. Aqil, R. Munagala, M. V. Vadhanam et al., "Anti-proliferative activity and protection against oxidative DNA damage by punicalagin isolated from pomegranate husk," Food Research International, vol. 49, no. 1, pp. 345-353, 2012.

[20] J. M. Landete, "Ellagitannins, ellagic acid and their derived metabolites: a review about source, metabolism, functions and health," Food Research International, vol. 44, no. 5, pp.1150-1160, 2011.

[21] C.-C. Lin, Y.-F. Hsu, and T.-C. Lin, "Effects of punicalagin and punicalin on carrageenan-induced inflammation in rats," American Journal of Chinese Medicine, vol. 27, no. 3-4, pp. 371376, 1999.

[22] C.-C. Lin, Y.-F. Hsu, T.-C. Lin, and H.-Y. Hsu, "Antioxidant and hepatoprotective effects of punicalagin and punicalin on acetaminophen-induced liver damage in rats," Phytotherapy Research, vol. 15, no. 3, pp. 206-212, 2001.

[23] P.-S. Chen, J.-H. Li, T.-Y. Liu, and T.-C. Lin, "Folk medicine Terminalia catappa and its major tannin component, punicalagin, are effective against bleomycin-induced genotoxicity in Chinese hamster ovary cells," Cancer Letters, vol. 152, no. 2, pp. 115-122, 2000.

[24] D. Heber, "Multitargeted therapy of cancer by ellagitannins," Cancer Letters, vol. 269, no. 2, pp. 262-268, 2008.

[25] D. M. Maron and B. N. Ames, "Revised methods for the Salmonella mutagenicity test," Mutation Research, vol. 113, no. 3-4, pp. 173-215, 1983.

[26] M. Zahin, I. Ahmad, and F. Aqil, "Antioxidant and antimutagenic activity of Carum copticum fruit extracts," Toxicology in Vitro, vol. 24, no. 4, pp. 1243-1249, 2010.

[27] D. M. Maron and B. N. Ames, "Revised methods for the Salmonella mutagenicity test," Mutation Research, vol. 113, no. 3-4, pp. 173-215, 1983.

[28] F. Aqil, M. V. Vadhanam, and R. C. Gupta, "Enhanced activity of punicalagin delivered via polymeric implants against benzo[a]pyrene-induced DNA adducts," Mutation Research: Genetic Toxicology and Environmental Mutagenesis, vol. 743, no. 1-2, pp. 59-66, 2012.

[29] R. C. Gupta, "32P-postlabeling for detection of DNA adducts," in Technologies for Detection of DNA Damage and Mutations, G. P. Pfeifer, Ed., pp. 45-61, Plenum Press, New York, NY, USA, 1996.
[30] W. P. Steward and K. Brown, "Cancer chemoprevention: a rapidly evolving field," British Journal of Cancer, vol. 109, pp. 1-7, 2013.

[31] A. H. Fang, W. A. Smith, P. Vouros, and R. C. Gupta, "Identification and characterization of a novel benzo[a]pyrenederived DNA adduct," Biochemical and Biophysical Research Communications, vol. 281, no. 2, pp. 383-389, 2001.

[32] J. M. Arif, M. Kunhi, Y. M. Siddiqui et al., "Differential modulation of benzo[a]pyrene-derived DNA adducts in MCF7 cells by marine compounds," International Journal of Cancer Prevention, vol. 1, pp. 259-268, 2004.

[33] E. Miadokova, I. Masterova, V. Vlckova, V. Duhova, and J. Toth, "Antimutagenic potential of homoisoflavonoids from Muscari racemosum," Journal of Ethnopharmacology, vol. 81, no. 3, pp. 381-386, 2002.

[34] M. Osborne and N. Crosby, Metabolism Benzopyrenes, Cambridge University Press, New York, NY, USA, 1987.

[35] S. Kaur, I. S. Grover, M. Singh, and S. Kaur, "Antimutagenicity of hydrolyzable tannins from Terminalia chebula in Salmonella typhimurium," Mutation Research: Genetic Toxicology and Environmental Mutagenesis, vol. 419, no. 1-3, pp. 169-179, 1998.

[36] J. M. Sayer, H. Yagi, A. W. Wood, A. H. Conney, and D. M. Jerina, "Extremely facile reaction between the ultimate carcinogen benzo[a]pyrene-7,8-diol 9,10-epoxide and ellagic acid," Journal of the American Chemical Society, vol. 104, no. 20, pp. $5562-$ $5564,1982$.

[37] M. Larrosa, F. A. Tomás-Barberán, and J. C. Espín, “The dietary hydrolysable tannin punicalagin releases ellagic acid that induces apoptosis in human colon adenocarcinoma Caco-2 cells by using the mitochondrial pathway," Journal of Nutritional Biochemistry, vol. 17, no. 9, pp. 611-625, 2006. 

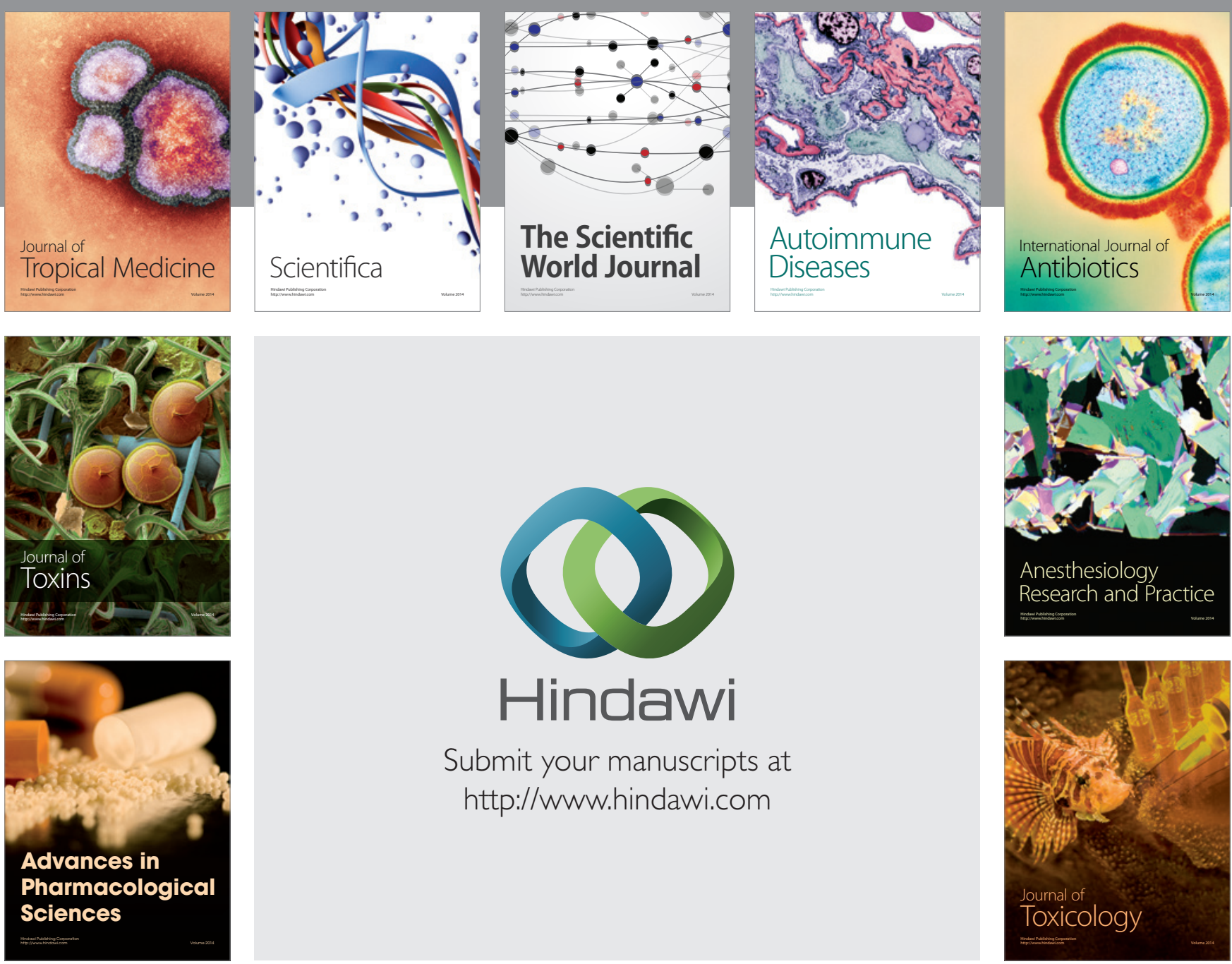

\section{Hindawi}

Submit your manuscripts at

http://www.hindawi.com
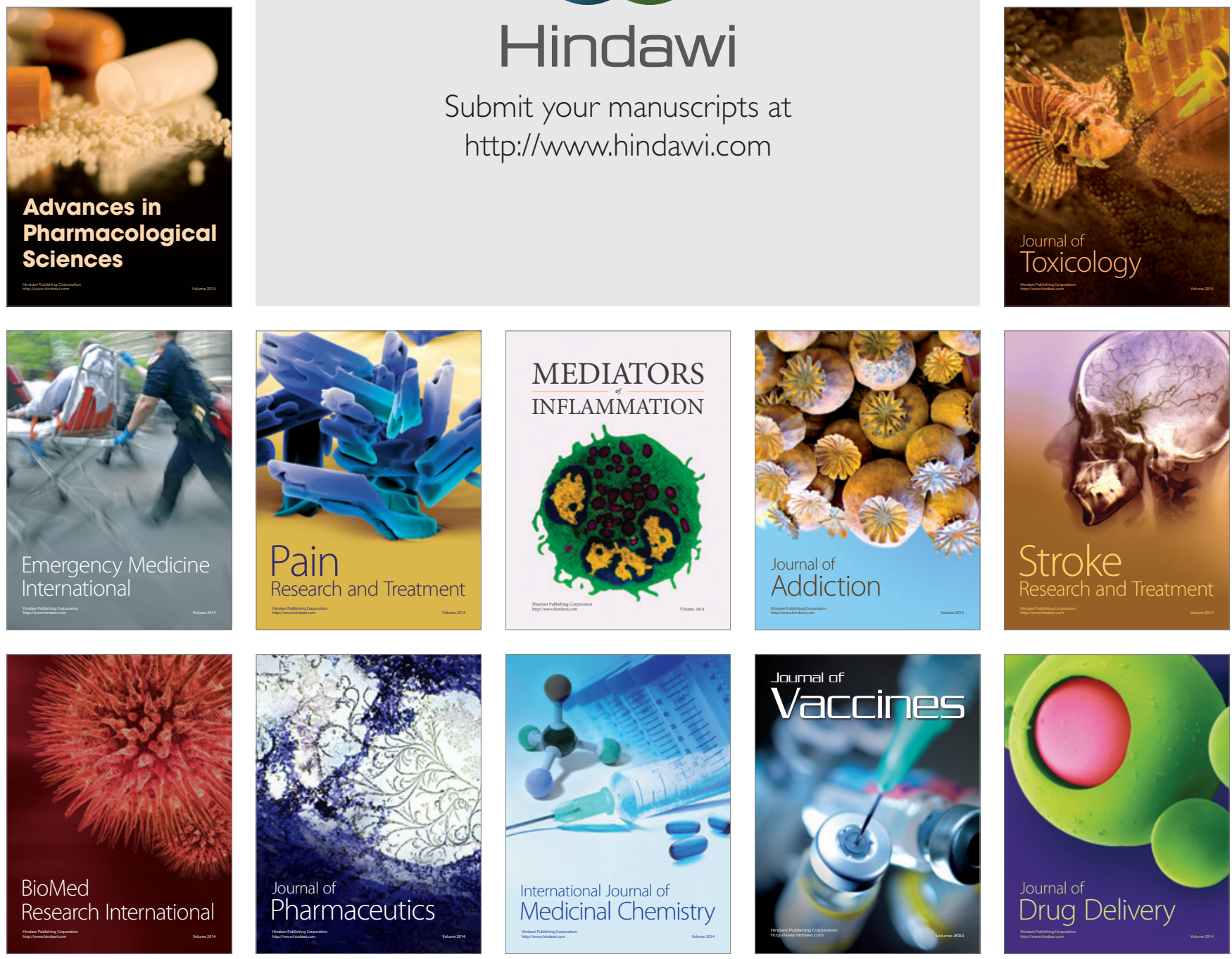